\title{
Field Evaluation of Bt Cotton Crop Impact on Nontarget Pests: Cotton Aphid and Boll Weevil
}

\author{
ER SujII ${ }^{1}$ Phb Togni ${ }^{2}$, P de A Ribeiro ${ }^{3}$, T de A Bernardes ${ }^{4}$, PVGN Milane $^{4}$, DP Paula ${ }^{1}$, CSS Pires $^{1}$, \\ EMG FONTES ${ }^{1}$
}

${ }^{1}$ Embrapa Recursos Genéticos e Biotcnologia-Cenargen, Brasilia, DF, Brasil

${ }^{2}$ Univ Federal de Viçosa, Viçosa, MG, Brasil

${ }^{3}$ Univ de Brasilia, Brasília, DF, Brasil

${ }^{4}$ Centro Universitário de Brasília-UNICEUB, Brasília, DF, Brasil

\section{Keywords}

Biosafety, cry toxin, herbivory, nontarget organism, sustainable pest management

\section{Correspondence}

ER Sujii, Embrapa Recursos Genéticos e Biotcnologia-Cenargen, Parque Estação Biológica-PqEB-Final Av. W5 norte, 70770917, Brasilia, DF, Brasil; edison.sujii@embrapa.br

Edited by Jorge B Torres - UFRPE

Received 14 November 2011 and accepted 1 October 2012

Published online 14 November 2012

(C) Sociedade Entomológica do Brasil 2012

\begin{abstract}
Bt cotton plants expressing Cry1Ac protein have high specificity for the control of lepidopteran larvae. However, studies conducted in several countries have shown these plants have a differential impact on nontarget herbivores. The aim of this study was to compare the colonization rates and population abundance of the cotton aphid, Aphis gossypii Glover (Hemiptera: Aphididae) and the boll weevil, Anthonomus grandis Boheman (Coleoptera: Curculionidae), in plots of Bt (Nuopal) and non-Bt cotton (Delta Opal) in an experimental field in Brasilia, DF, Brazil. No difference was observed in the preference and colonization by winged aphids to plants from the two treatments. There was no significant difference in abundance of wingless aphids or in the production of winged aphids between treatments. Apparently, the parameters that control factors such as fecundity, survival, and dispersal were similar on both Bt and non-Bt plants. Monitoring of plants for coccinellids, a specialist predator of aphids, and ants that act on the dispersal of aphids among plants showed no significant difference between $\mathrm{Bt}$ and non-Bt plants, supporting the inference above. Regarding the effect on boll weevil, there was also no significant difference between treatments in the total number of fruiting structures attacked in each plot, the percentage of fruiting structures attacked per plant or on the number of weevils emerging from fruits with boll weevil damage from egglaying, when damaged fruit samples were held in the laboratory. Based on these results, we conclude that there is no impact of Bt cotton crop expressing Cry1Ac on the nontarget herbivores tested under field conditions.
\end{abstract}

\section{Introduction}

Bt cotton is a genetically modified plant with genes expressing insecticidal proteins from Bacillus thuringiensis Berliner (Bt), such as Cry toxins and vegetative insecticidal proteins. The varieties available for sale in many countries provide protection to plants against Lepidoptera larvae (Estruch et al 2006, Perlak et al 2001, Naranjo et al 2008, Lawo et al
2009). This protection occurs throughout almost the entire crop cycle and in all parts of the plant, so there may be a reduction in the number of applications of synthetic chemical insecticides to larval control (Sharma \& Ortiz 2000, Wu 2004). Therefore, this technology is an important tool for use in management programs for cotton pests (Fitt 2008).

Insertion of a new gene may cause changes in plant quality as food for herbivorous insects, favoring their 
reproductive ability or survival on the plant (Thu Cuc et al 2008). Furthermore, the expression of a new protein can change plant/insect interactions causing shifts in the preference and oviposition behavior of females, with direct impact on the abundance of these species (Fontes et al 2002). The Bt protein produced by the plant may also indirectly affect nontarget herbivorous once it is ingested. Subsequently, it may negatively affect higher trophic levels (predators and parasitoids), releasing them from natural biological control and increasing their damage to cotton (Andow \& Zwahlen 2006, Suji et al 2006).

Brazil's cotton crop area was estimated at about 856,000 ha in the $2005 / 2006$ season (Conab 2007), including Bt cotton covering about 120,000 ha in its first year of postcommercial release (ISAAA 2006). The increasing adoption of transgenic technology in Brazil makes it vital to conduct a risk analysis of Bt cotton on herbivory of nontarget species, such as Aphis gossypii Glover (Hemiptera: Aphididae) and the boll weevil, Anthonomus grandis Boheman (Coleoptera: Curculionidae). These pests are selected as indicators due to their economic importance, wide geographical distribution and ecological relevance to cotton-growing regions (Suji et al 2006).

Aphis gossypii causes significant direct damage in the initial phase of the crop, weakening the plant and transmitting viruses that cause diseases and affect plant growth, and at the end of the cycle, when its attack reduces fiber quality (Fontes et al 2006). The boll weevil is the pest with the greatest potential for damage during the reproductive phase in the Neotropical region (Santos 2007) due to its capacity to withstand fallow periods between crops by feeding on pollen as an alternative resource (Ribeiro et al 2010). It also presents a high potential to outbreak in the next season by feeding and reproducing on squares and bolls (Santos 2007).

Laboratory studies conducted in India with three varieties expressing Cry1Ac rendered no difference in the performance of $A$. gossypii (Lawo et al 2009). In Brazil, studies conducted in the greenhouse by comparing the bionomics of $A$. gossypii did not show any effect of the transgenic variety expressing Cry1Ac on insect population dynamics (Sujii et al 2008). Field studies conducted in the USA (Sisterson et al 2004), South Africa (Vaissayre et al 2005), Australia (Whitehouse et al 2005), and China (Wu \& Guo 2003) showed no differences in the abundance of $A$. gossypii. However, a study in laboratory conditions showed that aphids fed on Bt cotton had higher reproductive capacity and higher survival rates if compared with individuals fed on non-Bt cotton, with a possible impact on the population dynamics of this species in China (Liu et al 2005). Additionally, assessments of the aphid populations on Bt and non-Bt cotton fields in another region of China showed a greater abundance of aphids in plots of Bt cotton
(Deng et al 2003). More recently, geographically broader studies have revealed an increase in the abundance of bug pests in areas cultivated with Bt cotton in China (Lu et al 2010).

Because of the restricted origin and distribution of boll weevil in the Americas (Burke et al 1986) and its eradication from cotton-producing areas of the USA (USDA-APHIS 2006), there is no study on the potential impact of planting Bt cotton on this important pest in Brazil and other South American countries.

Contradictory results in the literature on the effects of Bt cotton on Hemiptera and the lack of studies on the impact of Bt cotton on boll weevil populations suggest that there is a need to improve the ecological risk analysis. The following risk hypotheses were stated in the problem formulation of a formal environmental risk assessment model (Wolt et al 2010): (1) Bt cotton plants can be recognized by aphids and boll weevil changing the plant-insect interaction and the pest colonization rate; (2) the negative effect of transgenic plants on the predator-prey interaction reduces biological control of aphids allowing frequent outbreaks; and (3) Bt cotton affects the aphids-ants interaction changing the secondary dispersion of the pest and changes its abundance. The confirmation of at least one hypothesis can increase the abundance of $A$. gossyoii or $A$. grandis, which would result in the adverse effect of reduced crop production due to the damage potential of these pests.

We propose to develop an improved method to assess the entire risk hypothesis in a single field experiment with nontarget pest populations. The aim of this study was to evaluate the potential impact of Bt cotton on the abundance of the two nontarget species selected by a group of experts in cotton pests in Brazil (Sujii et al 2006), A. gossypii and $A$. grandis, in the field with a broader ecological approach.

\section{Material and Methods}

\section{Description of the experimental area}

The fieldwork was conducted at Embrapa Recursos Genéticos e Biotecnologia (Cenargen), Brasília, Brazil $\left(15^{\circ}\right.$ $\left.73^{\prime} S, 47^{\circ} 90^{\prime} \mathrm{W}\right)$. The experimental field has a total area of 2.4 ha of oxisol, and an area of $20 \times 50 \mathrm{~m}$ was used for the experiment. Cotton was planted in the 2008 crop season on 12 December 2007 and in the 2009 crop season on 05 January 2009. Both crop seasons followed randomized experimental design in blocks with two treatments: Bt cotton (Nuopal) and its nontransformed isoline (DeltaOpal) with five replicates per treatment. Each plot was composed of ten rows of $10 \mathrm{~m}$ with $0.9-\mathrm{m}$ spacing 
between rows and a density of 8-10 plants/m. Tillage practices, fertilization, and weed management were performed according to the technical recommendations for the Cerrado biome (Fundo de Apoio a Cultura do Algodão 2006, Freire 2007).

\section{Cry1Ac expression monitoring in Bt cotton}

The level of Cry1Ac toxin expression was monitored throughout the phenological cycle of the cotton crop in 2008 and 2009. Leaf samples were collected periodically at each stage of the cycle in five replicates from the same plots (Bt and non-Bt) where aphids and boll weevils were to be sampled: phase 1, vegetative (15 days after planting); phase 2 , beginning of the reproductive phase (30 days after planting); phase 3, flowering (6o days after planting); phase 4, fruiting (80 days after planting); and phase 5, senescence (130 days after planting).

The plant materials were weighed into aliquots of $1 \mathrm{~g}$ and stored at $-20^{\circ} \mathrm{C}$ before used to prepare samples for Cry1Ac toxin content analysis. Plant materials were macerated in liquid nitrogen until a fine powder was obtained. They were then homogenized in $3 \mathrm{~mL}$ of iced sodium phosphate buffer at $\mathrm{pH} 7.4$ (1x phosphate-buffered saline-PBS; $8 \mathrm{~g} \mathrm{NaCl} ; 0.2 \mathrm{~g} \mathrm{KCl} ; 1.4 \mathrm{~g}$ of $\mathrm{Na}_{2} \mathrm{HPO}_{4}$; and $0.2 \mathrm{~g}$ $\mathrm{KH}_{2} \mathrm{PO}_{4}$ in $1 \mathrm{~L}$ of deionized water), following subsequent removal of debris by centrifugation $\left(10,000 \mathrm{~g} \times 15 \min \times 4^{\circ} \mathrm{C}\right)$. The estimated average content of foliar Cry1Ac content was performed by enzyme linked immunosorbent assay (ELISA) using the SDI Bt1Ac Gehaka ${ }^{\circledR}$ kit, according to the manufacturer's protocol. To construct the standard curve, pure Cry1Ac trypsinized (about $65.5 \mathrm{kDa}$ ), produced by Dr. Pusztai-Carey (Department of Biochemistry, Case Western Reserve University, Cleveland, Ohio, USA), was solubilized in $0.05 \mathrm{M}$ sodium carbonate buffer, $\mathrm{pH} 9$ at 20, 10, 5, 2.50, 1.25, 0.675, 0.3125 , and $\mathrm{o} \mathrm{ng} /$ well in triplicate. The Cry1Ac standards and the samples (all normalized to $100 \mathrm{ng}$ of total protein by Qubit Fluorimetric Protein Quantification-Invitrogen ${ }^{\circledR}$ ) were applied to $100 \mu \mathrm{L} /$ well in ELISA plate of 96 wells (Nunc Maxisorp ${ }^{\circledR}$ ) already adsorbed with anti-Cry1Ac antibody. The plate was incubated under gentle agitation for $1 \mathrm{~h}$ at room temperature and washed three times with $100 \mu \mathrm{L} /$ well of PBS containing $0.1 \%$ of Tween 20 (PBST). The anti-IgG secondary antibody conjugated with peroxidase was applied at $100 \mu \mathrm{L} /$ well and incubated under gentle agitation for $1 \mathrm{~h}$ at room temperature. After three washes in PBST, the chromogenic substrate $3^{\prime}, 3^{\prime}, 5^{\prime}, 5^{\prime}$-tetrametilbenzidine was incubated at $100 \mu \mathrm{L} /$ well under gentle agitation at room temperature. After $30 \mathrm{~min}$, the reaction was stopped with $100 \mu \mathrm{L} /$ well of $1 \mathrm{~N}$ sulfuric acid to record the absorbance at $450 \mathrm{~nm}$ on a Benchmark Plus Microplate Spectrophotometer by Bio-Rad ${ }^{\circledR}$. The average levels of toxin were estimated in cotton leaves in micrograms of
Cry1Ac per gram of fresh leaves against a standard curve and compared by analysis of variance (ANOVA) and by multiple comparisons Tukey's test $(\alpha=0.05)$.

\section{Impact of Bt cotton on aphids}

The monitoring of the aphid population was performed three times per week from 26 December 2007 to 21 January 2008 for the first trial and from 19 January to 13 February 2009 for the second trial. This period corresponds to the beginning of the crop cycle, a phase in which there are higher immigration rates of $A$. gossypii to cotton fields. In each sample, we randomly designated five rows in which ten plants per row were randomly marked, totaling 50 plants sampled per plot. The abundance of winged and wingless $A$. gossypii in addition to the presence of coccinellids and ants associated with aphids was recorded for each plant. Wingless aphids were counted up to a maximum of 50 individuals. When more than 50 individuals were observed, we rated them as a large colony. Groups with 6 to 50 individuals were classified as medium colonies and with up to five individuals were considered small for analysis of the density of wingless aphids. We used a magnifying glass $(\times 10)$ of $10 \mathrm{~cm}$ in diameter to assist in the counting of aphids, reducing contact with the plant and, consequently the flight of winged forms. There was no insecticide application in the area during the experiment.

The proportion of infested plants and the density of winged adults per plot in Bt cotton and non-Bt throughout the collection period were used to estimate the rate of primary colonization of the plots. The proportion of plants attacked by winged and wingless aphids were compared by ANOVA. The average number of plants with ants and the average number of coccinellids per plot were compared by $t$ test. The proportion of plants with different sizes of colonies of aphids and without colonies was compared across sampling dates using the Kolmogorov-Smirnov test for two samples and their similarity was compared by Bray-Curtis coefficient (Hammer et al 2001). The data on average rainfall during the period of this study were provided by Companhia de Saneamento Ambiental do Distrito Federal from the Northern Sewage Treatment Station (ETENorth; $\left.15^{\circ} 44^{\prime} \mathrm{S}, 47^{\circ} 72^{\prime} \mathrm{W}\right)$, which is located $800 \mathrm{~m}$ from the experimental field.

\section{Impact of Bt cotton on boll weevil}

The monitoring of the attack of the boll weevil in both years was made from the appearance of flower buds (about 30 days after planting) in February through fortnightly samples of flower buds (squares) and bolls in the same field experiment described above. The samples were 
collected according to Degrande (1991), which consists in the collection of reproductive structures (flower buds and bolls) from the upper middle third of the tallest plant, as well as the structures found on the ground. The sampled plant was marked to avoid resampling.

A subsample of two buds or bolls with symptoms of boll weevil attack, characterized by the presence of oviposition marks, was taken from each sample plant. Each flower bud or boll was isolated in a 250-mL plastic pot and stored in an environmental chamber at $25 \pm 2{ }^{\circ} \mathrm{C}, 60 \% \mathrm{RH}$, and $13 \mathrm{~h}$ photophase, to evaluate adult emergence.

The variables were number of reproductive structures attacked by boll weevil and proportion of attacked plants per plot, number of weevils emerged per plot, and reproductive structures. These were compared by $t$ test or Kolmogorov-Smirnov test for two samples and two-factor ANOVA. All statistical analyses were performed using the SigmaStat v. 3.1 (SYSTAT 2004) and PAST (Hammer et al 2001). When the data did not allow for parametric testing, an analysis was performed based on a generalized linear model (GLM) to fit the negative binomial distribution using the software R. In this case, the variables were compared by analysis of deviance (R Development Core Team 2009).

\section{Results and Discussion}

\section{Expression of the Cry1Ac toxin by Bt cotton}

A reduction in Cry1Ac expression was observed as plant development advanced (Fig 1). Cry1Ac foliar expression was dissimilar at various stages of the cotton cycle (ANOVA, $F_{4,23}=34.66$, $P<0.0001$ for the 2008 season and $F_{4,23}=22.36, P<0.0001$ for the 2009 season). In the 2008 and 2009 seasons, respectively, the expression was higher at the beginning of the vegetative stages (4.36 and $3.39 \mu \mathrm{g} / \mathrm{g}$ of fresh leaf), followed by a sharp decrease at the beginning of the reproductive phase (0.50 and $0.89 \mu \mathrm{g} / \mathrm{g}$ of fresh leaf). A recovery in concentration was observed in the middle of the reproductive phase ( 2.28 and $1.89 \mu \mathrm{g} / \mathrm{g}$ of fresh leaf) but followed again by a decrease in concentration at the peak of boll production ( 0.64 and $0.48 \mu \mathrm{g} / \mathrm{g}$ of fresh leaf). Finally, it reached the lowest concentration at the end of the cycle $(0.15$ and $0.08 \mu \mathrm{g} / \mathrm{g}$ of fresh leaf).

A similar profile of decreased concentration of Cry1Ac expression in leaf tissues with the progress of the vegetal physiological stage was reported in other studies, where the variations observed for the same stage of development were supposedly attributed to environmental factors (Benedict et al 1996, Fitt 1998, Sachs et al 1998, Greenplate 1999, Olsen et al 2005). The reduction in the level of Cry1Ac in various plant tissues is predominantly associated with metabolic changes due to the onset of the reproductive stage (de Carvalho et al 1992, Hart et al 1992, Palauqui \& Vaucheret 1995).

The expression of Cry1Ac in Nuopal variety declined by about 29-fold in the 2008 season (from 4.36 to $0.15 \mu \mathrm{g} / \mathrm{g}$ of fresh leaf) and about 42-fold in the 2009 season (from 3.39 to $0.08 \mu \mathrm{g} / \mathrm{g}$ of fresh leaf) from the vegetative phase to senescence (Fig 1). Benedict et al (1996) observed a decrease in foliar Cry1Ac expression of around two fold in two out of seven Bt cotton varieties studied. Greenplate (1999) observed a 5-fold decline in foliar Cry1Ac level of along the Bt cotton crop phenology. Sachs et al (1998) found the same foliar decline in Cry1Ac level with plant ageing in five out of six varieties of Bt cotton. However, they pointed out that despite this fall, the proportion of the toxin in relation to the total amount of protein becomes progressively larger, meaning that it is the total amount of protein that declines as the plant matures.

The Nuopal variety showed constitutive expression, albeit irregular, of Cry1Ac toxin during the entire growth and
Fig 1 Average expression of Cry1Ac throughout the phenological cycle of Bt cotton (variety Nuopal) in two planting dates (vertical bars indicate the standard deviation associated with each mean value).

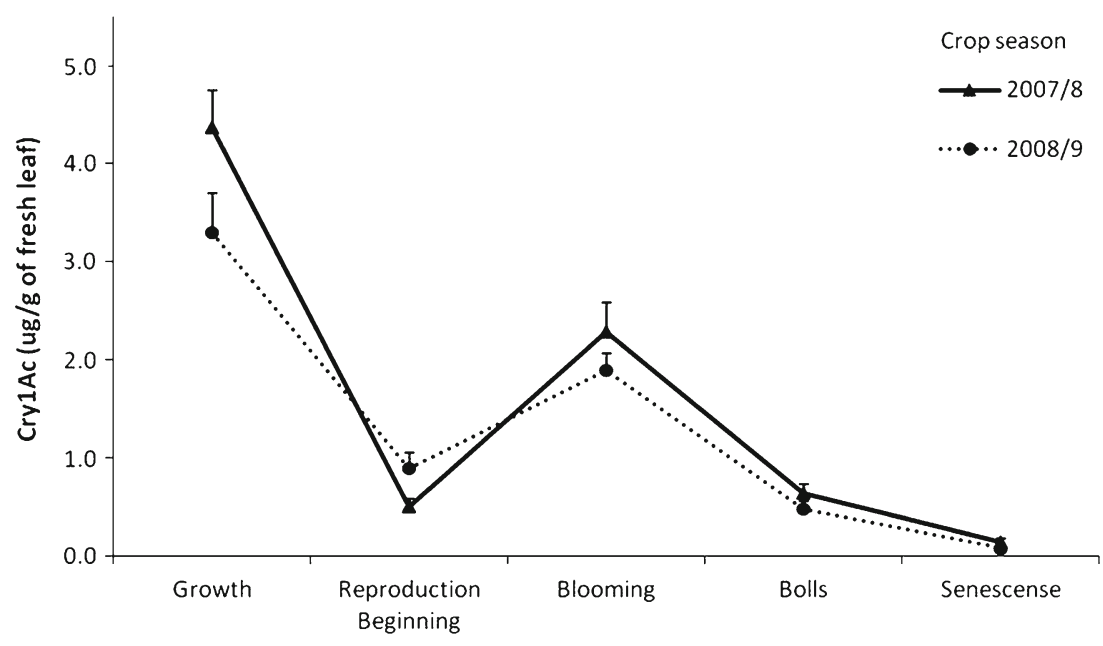

Bt cotton phenological stage 
development of the plant. The variation temporal decay in the levels of the Bt toxin is highly relevant to pest and resistance management to the toxin. Based on this information, it is possible to identify the most susceptible crop period to pest attack and apply other management strategies in these periods.

\section{Impact of Bt cotton on aphids}

An intense aphid outbreak occurred at the beginning of the crop cycle. The outbreak coincided with low rainfall $(19 \mathrm{~mm}$ rainfall in 21 days and $<1 \mathrm{~mm}$ in 15 days), immediately after crop emergence in 2008. Winged aphids were observed in $6-26 \%$ of the plants in the first sampling on 27 December. The proportion of plants attacked increased by midJanuary when the highest levels of infested plants were observed (Fig 2a). Despite the temporal variation of the population of winged adults throughout the observation period, there was no difference in the proportion of infested plants. The amount of winged adults per plot in the Bt variety (Nuopal) as compared with non-Bt plants (Delta Opal) did not differ (GLM 2008-variety, ns.; sampling date, $F_{11,58}=2.15, P=0.032$; interaction, ns). Densities of winged aphids were initially lower in the 2009 crop season, ranging from $0 \%$ to $12 \%$ of plants infested in the first sampling (Fig 2b).

Aphid abundance had no defined peak, and no significant changes were seen either in the proportion of infected plants or in the abundance of individuals per plot between the sampling dates (GLM 2009-variety, ns; sampling date, $F_{11,58}=-2.42, P=0.015$; interaction, ns). This pattern may have been affected by heavy and concentrated rain at the beginning of January $(266.8 \mathrm{~mm})$. Overall, there were no differences in the proportion of plants attacked or the abundance of individuals per plot between $\mathrm{Bt}$ and non-Bt varieties in both of the crop seasons studied.

These data suggest that the winged adults do not exhibit a differentiated pattern between Bt and non-Bt cotton. Likewise, the amount of winged adults that emerge from the colonies, as well as the new migrant settlers arriving in the area, keep the aphids in similar densities on Bt and non-Bt cultivars. According to Powell et al (2006), aphids in general must pass through the following stages to select their host plant: (1) phototactic stimulus for landing, (2)
Fig 2 Proportion of Bt cotton plants (Nuopal) and non-Bt cotton (Delta Opal) attacked by winged aphid, Aphis gossypii, in the a 2007/2008 and b 2008/ 2009 seasons. (ANOVA 2008variety, ns; sampling date, $F_{14,73}=$ 14.47, $P<0.001$; interaction, $\mathrm{ns}$; 2009-variety, ns; sampling date, $F_{11,58}=2.53, P=0.008$;

interaction, ns).
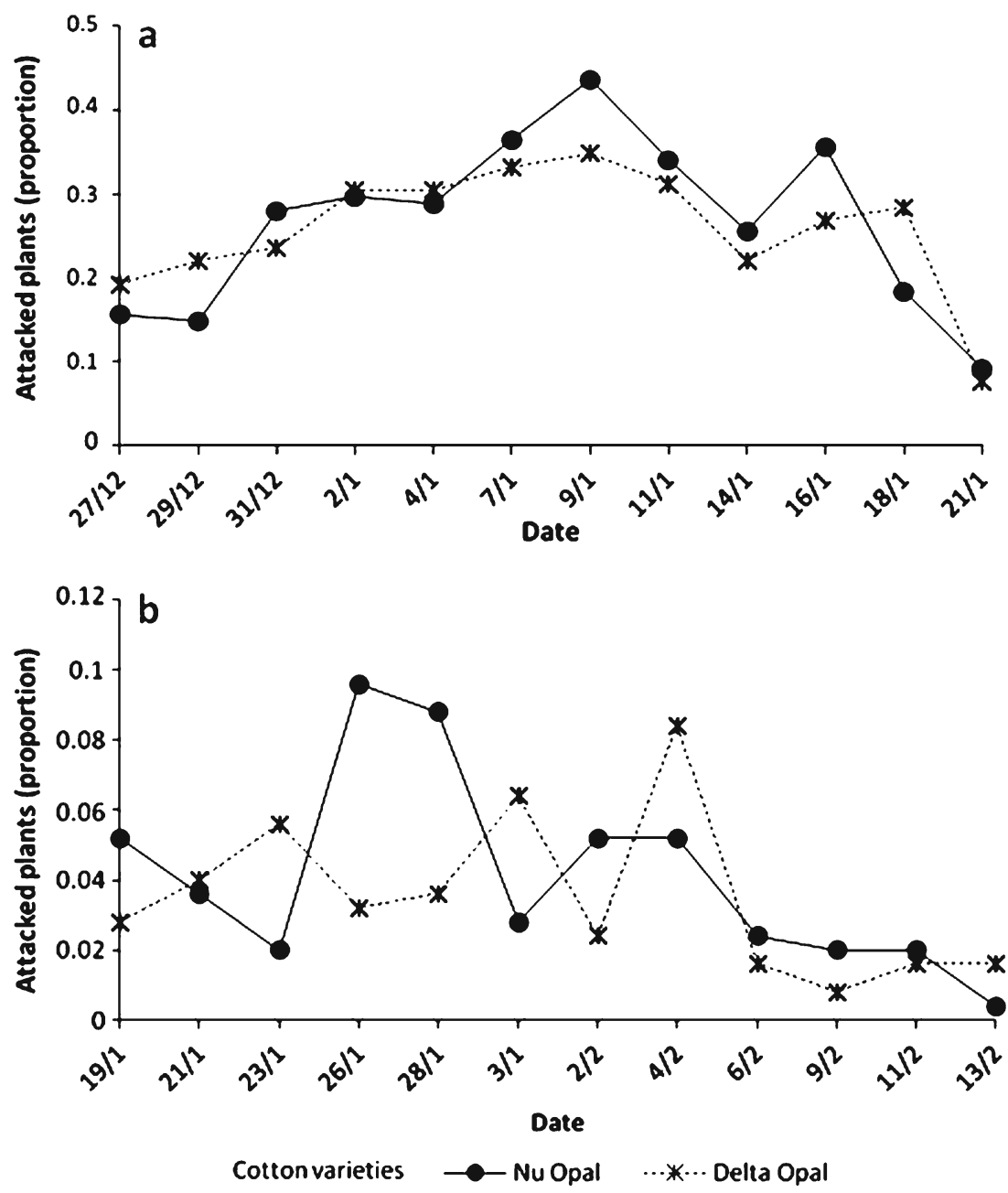
initial contact with chemical cues on the plant surface, (3) evidence of the cellular content of the epidermis, (4) evidence of parenchyma and mesophyll, (5) injection of saliva into the leaf cells, and (6) consumption of mobile content and acceptance of the plant as a host. Changes in the physiology of the host plant can alter some of these stages and result in behavioral changes or otherwise affect the bionomics of aphid population (Petterson et al 2007). Changes in plant physiology between the two cotton varieties certainly had an impact on the aphid population patterns observed in this former study. However, the results presented here indicate that the insertion of the transgene did not cause enough physiological change between varieties to significantly affect aphid population abundance in any of these steps of $A$. gossypii colonization and establishment in the studied area.

There was no difference in the proportion of plants attacked by wingless aphids between the varieties in either the 2008 or 2009 crop seasons (Figs 3a, b). Wingless individuals were observed in $60-84 \%$ of plants in each plot in the first sampling of the crop in 2008 and had increased by the end of the second half of January (Fig 3), which is consistent with the infestation and density of alatae aphids. The proportion of plants attacked by wingless aphids at harvest in 2009 was initially lower than in the 2008 crop (Fig 3b). There was an increase in the abundance of wingless aphids along the crop season in 2009 and from 2 February, all plants had wingless aphids, a condition which continued until the end of the sampling period.

These data confirm the pattern observed in previous years and support the inference that cotton plants of the variety Nuopal expressing the Cry1Ac protein do not affect plant colonization by winged adults of $A$. gossypii. The results obtained in this field study confirm those made by Sujii et al (2008) in the greenhouse. They found that there were no significant differences in the biological parameters examined for $A$. gossipii raised on Bt and non-Bt cotton.

Data on the relative size of colonies of aphids during the collection period also showed no significant differences between $\mathrm{Bt}$ and non-Bt varieties in the 2008 and 2009 seasons when compared by Kolmogorov-Smirnov test for two samples (Table 1). Aphid colony sizes on Bt versus nonBt cotton showed a high degree of similarity (usually above
Fig 3 Proportion of Bt cotton and non-Bt plants attacked by wingless individuals of Aphis gossypii in the a 2007/ 2008 and b 2008/2009 seasons (ANOVA 2008-variety, ns; sampling date, $F_{14,73}=$ 4.40, $P<0.001$; interaction, ns; 2009-variety, ns; sampling date, $F_{11,58}=2.65, P=$ 0.005 ; interaction, $\mathrm{ns}$ ).
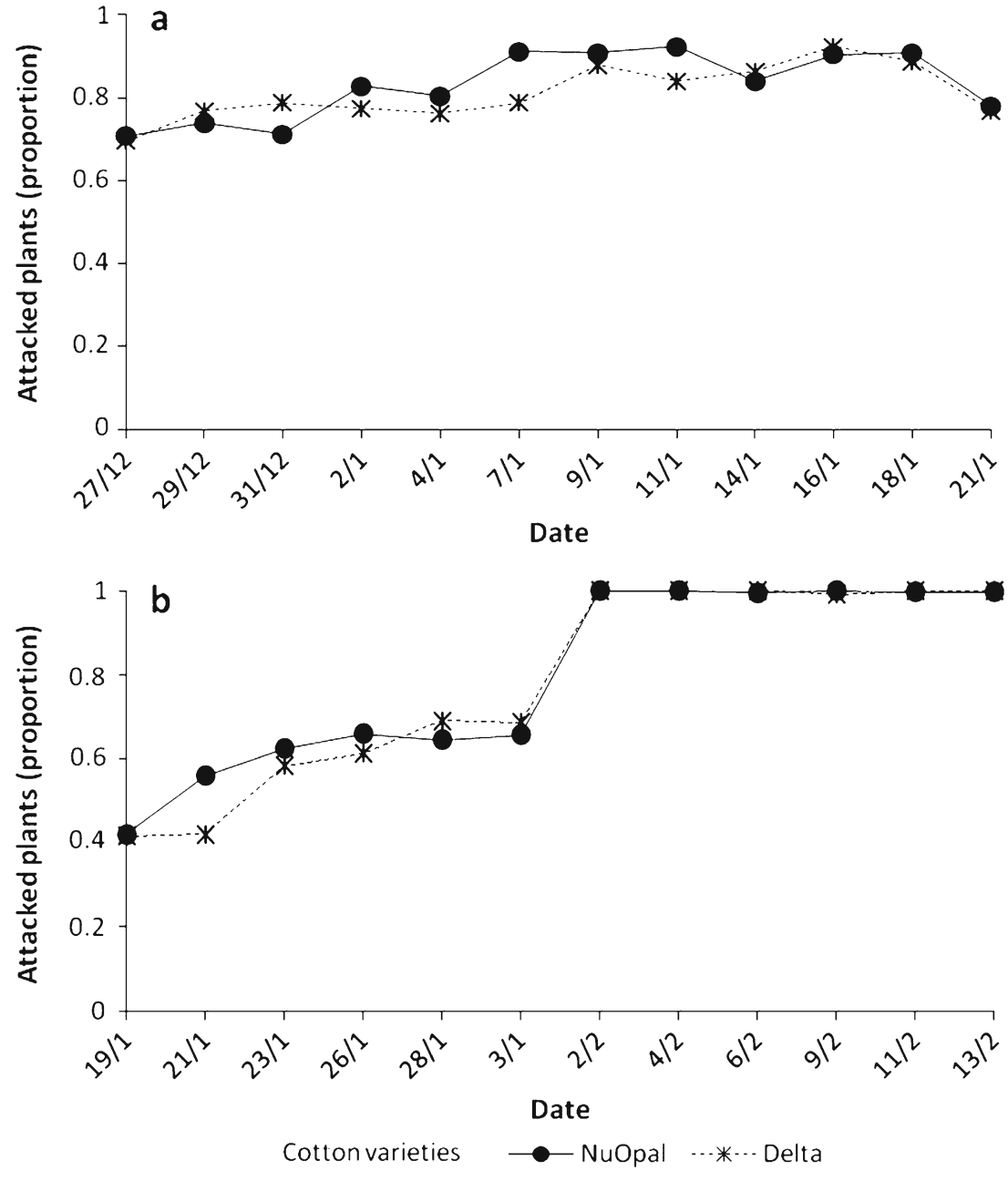
Table 1 Size distribution of colonies of wingless aphids in plots of Bt (Nuopal) and non-Bt cotton (Delta Opal) compared by the Kolmogorov-Smirnov test and the similarity coefficient of Bray-Curtis coefficient in the 2008 and 2009 seasons.

\begin{tabular}{|c|c|c|c|c|c|c|}
\hline \multirow[t]{2}{*}{ Colony size } & \multicolumn{3}{|l|}{2008} & \multicolumn{3}{|l|}{2009} \\
\hline & $D$ & $P$ & Bray-Curtis & $D$ & $P$ & Bray-Curtis \\
\hline Non-aphid plants & 0.2667 & 0.5589 & 0.8918 & 0.1667 & 0.9913 & 0.9363 \\
\hline Small & 0.1333 & 0.9913 & 0.9259 & 0.2500 & 0.7864 & 0.9577 \\
\hline Medium & 0.2000 & 0.8899 & 0.9349 & 0.1567 & 0.9910 & 0.9274 \\
\hline Large & 0.1333 & 0.9983 & 0.8988 & 0.2500 & 0.7864 & 0.7239 \\
\hline
\end{tabular}

89\%) when compared by the Bray-Curtis index (Table 1). This suggests that populations of $A$. gossypii increased equivalently in Bt and non-Bt plants in the 2 years of study.

There were no significant differences in the proportion of plants on which ladybugs were observed (Coleoptera: Coccinellidae) in plots with a Bt and non-Bt cotton in 2008 $\left(t_{28}=0.900, P=0.376\right)$ and $2009\left(t_{22}=1.195, P=0.245\right)$. Likewise, the proportion of plants with ants interacting with $A$. gossypii did not differ between treatments in $2008\left(t_{28}=0.612, P=0.546\right)$ and $2009\left(t_{22}=1.794, P=0.087\right)$.

Other biotic interactions that could affect the population fluctuation of aphids in cotton plants is biological control. Aphid-specific lady bird beetle predators are the most abundant group on cotton plants in the midwest of Brazil (Barros et al 2006, Sujii et al 2007). Populations of ladybeetles were not different between plots planted with Bt and non-Bt cotton. Likewise, ants use the honeydew of aphids as a food resource. They are known to disperse aphids by moving them between plants and defend aphids from predators (Buckley 1987), thereby contributing to aphid spatial distribution and population growth. However, in this study, the proportion of plants with ants interacting with $A$. gossypii did not differ between treatments. Then, the presence/absence of the Bt trait in the cotton cultivars tested had no impact on the incidence of ants nor coccinellids.

There is a possibility that successive generations of $A$. gossypii developing on Bt cotton could result in changes in the plant-insect interactions as reported by Liu et al (2005). However, the large number of host plant species of $A$. gossipii (90 botanical families) (Ebert \& Cartwright 1997) and the discontinuous nature of cotton crop sowing and harvesting periods, mediated by the well-defined dry season (Fundo de Apoio a Cultura do Algodão 2006, Freire 2007) provide isolation, which may be sufficient to avoid the selection of subpopulations better adapted to Bt cotton. The detection of changes in populations of $A$. gossypii and other pests does not greatly threaten the technology on a regional scale, as post-commercial release monitoring will be conducted for several years by the National Technical Commission on Biosafety (CTNBio 2008) as a part of the process of releasing genetically modified plants. This is an important point for consideration, the reduced use of insecticides to control larvae in commercial plantings of Bt cotton might result in higher aphid populations in the long term (Wu \& Guo 2005). We also suggest the joint monitoring of the populations of natural enemies of aphids that, despite being favored by the nonapplication of insecticides, may be unexpectedly affected by the transgene.

\section{Impact of Bt cotton on boll weevil}

Boll weevil was first detected in February and the highest infestations occurred during March and April in the 2008 and 2009 crop seasons, respectively. No differences in weevil damage to fruits collected on the plants or on the soil beneath plants were detected between Bt and non-Bt varieties. The amount of attacked reproductive structures (flower buds and bolls) per plot (mean \pm standard deviation) were as follows: Bt variety in the 2008 season $(36.1 \pm 10.38)$ and non-Bt $(34.4 \pm 10.45)$ and the Bt variety in the 2009 crop (35.3 \pm 10.12$)$ and non-Bt $(31.8 \pm 12.23)$. No difference was observed in these values between varieties in both years $\left(2008-t_{21}=0.3686, P=0.7163 ; 2009-t_{19}=0.6932\right.$, $P=0.497)$. These results indicate that adult females are not selecting oviposition sites based on the presence or absence of the Bt transgene.

The average number of reproductive structures attacked per plot, including those collected in plant and soil, did not differ between varieties in 2008 (ANOVA $-F_{1,10}=1.92, P=$ $0.169)$ or $2009\left(F_{1,9}=0.69, P=0.488\right)$. Although there were differences over the weeks of the season in both 2008 (ANOVA $\left.-F_{1,10}=15.51, P<0.0001\right)$ and $2009\left(F_{1,9}=3.07, P=\right.$ $0.002)$, there was no significant interaction between these factors. These results demonstrate that boll weevil abundance is related to seasonal variation in the quantity and quality of food and oviposition sites regardless of the variety. Likewise, the percentage of structures attacked by the boll weevil throughout the sampled period showed no difference between the varieties (Fig 4) (KolmogorovSmirnov test for two samples, 2008 $-D=0.272, P=0.7358$; $2009-D=0.200, P=0.9748)$. The average number of adults emerged per reproductive structure $\left(2008-t_{21}=\right.$ $\left.0.587, P>0.564 ; 2009-t_{19}=-0.323, P=0.7501\right)$ also showed no significant difference between the varieties tested (Fig 5). 
Fig 4 Percentage per plot of plants attacked by boll weevil in Nuopal cotton (Bt) and Delta Opal (non-Bt) on different dates in the a 2007/2008 and b 2008/2009 crop seasons.
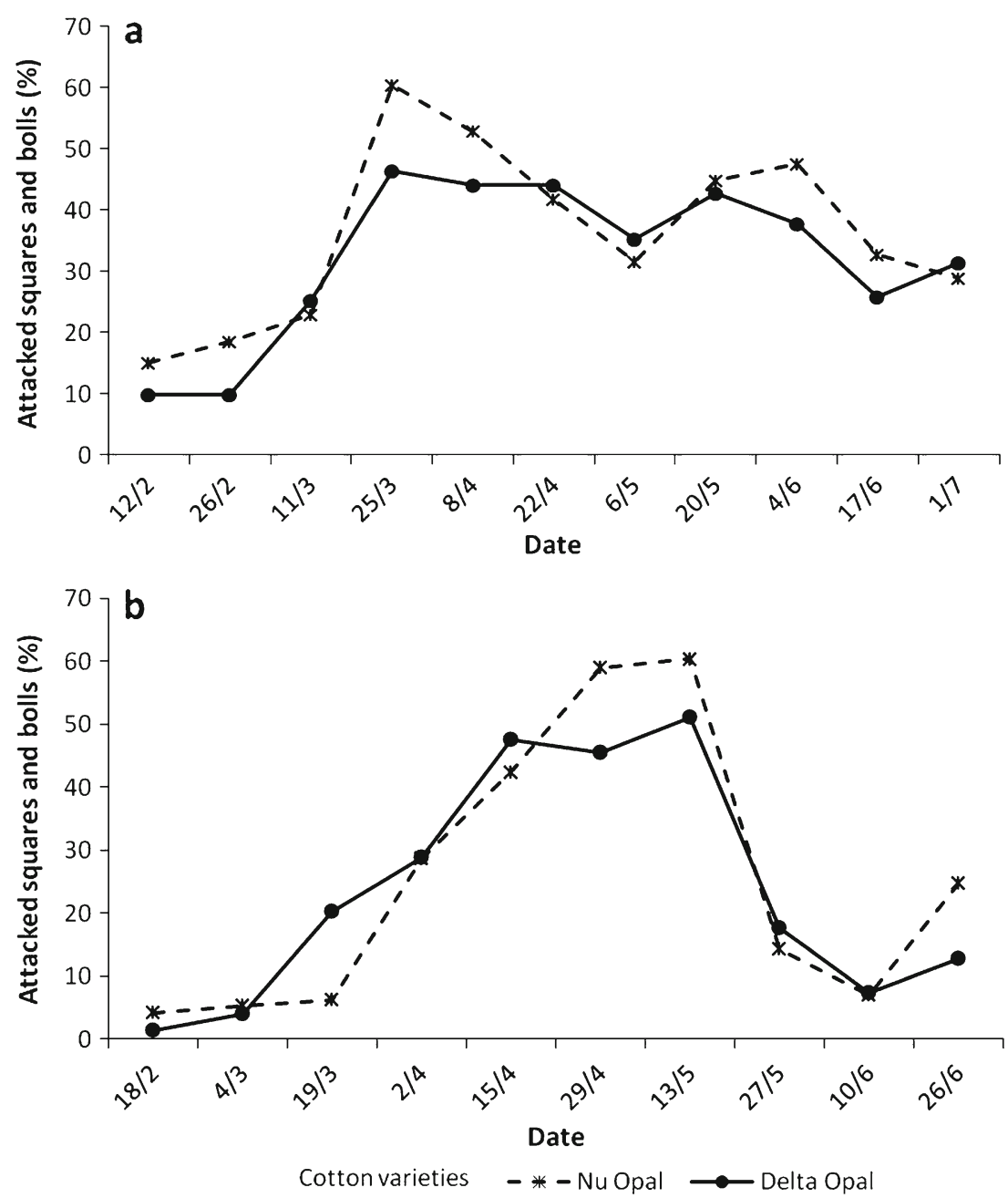

Damage of the boll weevil on Bt cotton was not different from that observed on its non-Bt isoline, either in the number of structures attacked or in the proportion of attacked plants. Thus, one can infer that in this case boll weevil females did not discriminate between varieties on which to lay their eggs. The average number of adults emerging from reproductive structures indicates that survival was equivalent in both varieties and the presence of the Bt toxin (or other factors) did not significantly influence boll weevil development. Therefore, the introduction of the transgene had no effect on this nontarget pest, similar to what was observed for the cotton aphid.

We propose a broader approach with a more comprehensive problem formulation based on biotic interactions such as plant-insect and insect-insect to assess the potential impact of genetically modified crops resistant to insect pests on nontarget herbivores in field conditions under controlled release. This differs from former studies based on insect bionomics or seasonal fluctuation of nontarget species populations without evaluating behavioral interactions. This approach does not only evaluate direct and immediate potential impacts but also allow for the evaluation of indirect and delayed impacts. Thus, it was established that a variety of Bt cotton expressing Cry1AC toxin has no potential to change the current status of $A$.

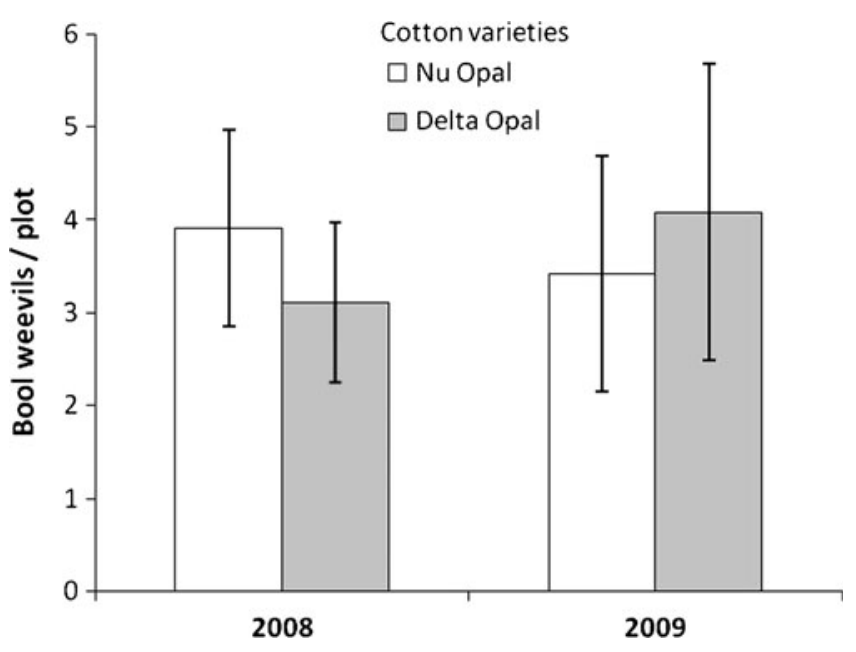

Fig 5 Average number of boll weevils emerged from reproductive structures collected from plots of Nuopal cotton (Bt) and Delta Opal (non-Bt) in two crop seasons. 
gossypii and $A$. grandis as nontarget insect pests due to plant-insect interactions and also that ecological interactions such as biological control and ant-aphid interactions were not impacted by Bt cotton cropping.

Acknowledgments The authors thank Marina M. Teixeira, Francisco M. Caldas, Vinicius A. Ferreira, and Adam Zeilinger for their help in data collection, Joseane Padilha da Silva for technical support in statistical analysis, and Renata Velozo Timbó for technical support in the analysis for immunodetection. CNPq is acknowledged for financial support (processes 479211/2007-8 and No. 304253/2007-3).

\section{References}

Andow DA, Zwahlen C (2006) Assessing environmental risks of transgenic plants. Ecol Lett 9:196-214

Barros R, Degrande PE, Ribeiro JF, Rodrigues ALL, Nogueira RF, Fernandes MG (2006) Flutuação populacional de insetos predadores associados a pragas do algodoeiro. Arq Inst Biol 73:57-64

Benedict JH, Sachs ES, Altman DW, Deaton WR, Kohel RJ, Ring DR, Berberich AS (1996) Field performance of cottons expressing transgenic Cry1A insecticidal proteins for resistance to Heliothis virescens and Helicoverpa zea (Lepidoptera: Noctuidae). J Econ Entomol 89:230-238

Buckley RC (1987) Interactions involving plants, Homoptera, and ants. Annu Rev Ecol Syst 18:111-135

Burke HR, Clark WE, Cate JR, Fryxell PA (1986) Origin and dispersal of the boll weevil. Bull Entomol Soc Am 32:228-238

Comitê Técnico Nacional de Biossegurança-CTNBIO. 2008. Resolução normativa número 05 . Available at: http://www.ctnbio.gov.br/ index.php/content/view/11444.html. Accessed 25 January 2011

CONAB (2007) Série Histórica de Produção. Available at: http://www. conab.gov.br/conabweb/download/safra/BrasilProdutoSerieHist.xls. Accessed 02 May 2011

de Carvalho F, Gheysen G, Kushnir S, Van Montagu M, Inze D, Castresana C (1992) Suppression of 1,3-glucanase transgene expression in homozygous plants. EMBO 11:2595-2602

Degrande PE (1991) Bicudo do algodoeiro: Táticas de controle para Mato Grosso do Sul. UFMS/NCA, Dourados, p 16

Deng SD, Xu J, Zhang QW, Zhou SW, Xu GJ (2003) Effect of transgenic Bacillus thuringiensis cotton on population dynamics of non-target pests and natural enemies. Acta Entomol Sin 46:1-5

Ebert TA, Cartwright B (1997) Biology and ecology of Aphis gossypii Glover (Homoptera: Aphididae). Southwest Entomol 22:116-153

Estruch JJ, Gregory GW, Mullins MA, Nye GJ, Craig JA, Koziel MG (2006) Vip3A, a novel Bacillus thuringiensis vegetative insecticidal protein with a wide spectrum of activities against lepidopteran insects. Proc Nat Acad Sci 93:5389-5394

Fitt GP (1998) Efficacy of Ingard cotton-patterns and consequences. In: Proceedings of the Ninth Australian Cotton Conference, Conrad, The Cotton Research and Development Corporation, pp. 233-245.

Fitt GP (2008) Have Bt crops led to changes in uses of insecticide use patterns and impacted IPM. In: Shelton AM, Kennedy GG (eds) Integration of insect-resistant genetically modified crops within IPM programs. Springer, New York, pp 303-328

Fontes EMG, Pires CSS, Sujii ER, Panizzi AR (2002) The environmental effects of genetically modified crops resistant to insects. Neot Entomol 31:497-513

Fontes EF, Ramalho FS, Underwood E, Barroso PAV, Simon MF, Sujii ER, Pires CSS, Beltrão N, Lucena WA, Freire EC (2006) The cotton agriculture context in Brazil. In: Hilbeck A, Andow DA, Fontes EMG (eds) Environmental risk assessment of genetically modified organisms volume 2: methodologies for assessing Bt cotton in Brazil. CABI, Wallingford, pp 21-66, 373

Freire EC (2007) Algodão no cerrado do Brasil. Mundial Gráfica e Editora, Brasilia, 917

Fundo de Apoio a Cultura do Algodão (2006) In: E Moresco (ed.) Algodão: pesquisa e resultados para o campo. FACUAL, Cuiabá. 392 $\mathrm{pp}$

Greenplate JG (1999) Quantification of Bacillus thuringiensis insect control protein (Cry1Ac) over time in Bollgard cotton fruit and terminals. J Econ Entomol 92:1377-1383

Hammer O, Harper DAT, Ryan PD. (2001) Paleontological statistics software package for education and data analyses. Paleontol Electr 4:1-9. Available at: http://palaeo-electronica.org/2001_1/past/ issue1_01.htm. Accessed 30 January 2011

Hart CM, Fischer B, Neuhaus JM, Meins FJ (1992) Regulated inactivation of homologous gene expression in transgenic Nicotiana sylvestris plants containing a defense-related tobacco chitinase gene. Mol Gen Genet 235:179-188

ISAAA (2006). Available at: http://www.agenciabrasil.gov.br/noticias/ 2007/01/18/materia.2007-01-18.9381176603/view). Accessed 03 August 2007

Lawo NC, Wackers FL, Romeis J (2009) Indian Bt cotton varieties do not affect the performance of cotton aphids. PLoS One 4:e4804

Liu XD, Zhai BP, Zhang XX, Zong JM (2005) Impact of transgenic cotton plants on non-target pest, Aphis gossypii Glover. Ecol Entomol 30:307-315

Lu Y, Wu K, Jiang Y, Xia B, Li P, Feng H. Wyckhuys KAG, Guo Y (2010) Mirid bug outbreaks in multiple crops correlated with wide-scale adoption of Bt cotton in China. Science 328:1151-1154

Naranjo SE, Ruberson JR, Sharma HC, Wilson L, Kongming W (2008) The present and future role of insect-resistant GM crops in cotton IPM. In: Romeis J, Shelton AM, Kennedy GG (eds) Integration of insect-resistant genetically modified crops within IPM programs. Springer, New York, pp 159-194, 441

Olsen KM, Daly JC, Holt HE, Finnegan EJ (2005) Season-long variation in expression of crylac gene and efficacy of Bacillus thuringiensis toxin in transgenic cotton against Helicoverpaarmigera (Lepidoptera: Noctuidae). J Econ Entomol 98:1007-1017

Palauqui JC, Vaucheret $\mathrm{H}$ (1995) Field trial analysis of nitrate reductase co-suppression: a comparative study of 38 combinations of transgene loci. Plant Mol Biol 29:149-159

Perlak FJ, Oppenhuizen M, Gustafson K, Voth R, Sivasupramaniam S, Heering D, Carey B, Ihrig RA, Roberts JK (2001) Development and commercial use of Bollgard cotton in the USA-nearly promises versus today's reality. Plant J 27:489-501

Petterson J, Tjallingii WF, Hardie J (2007) Host plant selection. In: Vam Emdem HF, Harrington R (eds) Aphids as crop pests. CABI, London, pp 87-114, 752

Powell G, Tosh GR, Hardie J (2006) Host plant selection by aphids: behavioral, evolutionary, and applied perspectives. Annu Rev Entomol 52:309-330

R Development Core Team (2009) R: A language and environment for statistical computing. R Foundation for Statistical Computing, Vienna, 409

Ribeiro PA, Sujii ER, Diniz IR, Medeiros MA, Salgado-Laboriau ML, Branco MC, Pires CSS, Fontes EMG (2010) Alternative food sources and overwintering feeding behavior of the boll weevil, Anthonomus grandis Boheman (Coleoptera: Curculionidae) under the tropical conditions of Central Brazil. Neotrop Entomol 39:28-34

Sachs ES, Benedict JH, Stelly DM, Taylor JF, Altman DW, Berberich SA, Davis SK (1998) Expression and segregation of genes encoding Cry1A insecticidal proteins in cotton. Crop Sci 38:1-11

Santos WJ (2007) Manejo de pragas do algodão com destaque para o cerrado brasileiro. In: FREIRE EC (ed) Algodão no 
cerrado do Brasil. Mundial Gráfica e Editora, Brasilia, pp 403478, 917

Sharma HC, Ortiz R (2000) Transgenics, pest management, and the environment. Curr Sci 79:421-437

Sisterson MS, Biggs RW, Olson C, Carrière $Y$, Dennehy TJ, Tabashnik BE (2004) Arthropod abundance and diversity in Bt and non-Bt cotton fields. Environ Entomol 33:921-929

Sujii ER, Lövei GL, Sétamou M, Silvie P, Fernandes MG, Dubois GSJ, Almeida RP (2006) Non-target and biodiversity impacts on nontarget herbivorous pests. In: Hilbeck A, Andow DA, Fontes EMG (eds) Environmental risk assessment of genetically modified organisms volume 2: methodologies for assessing Bt cotton in Brazil. CABI, Wallingford, pp 133-154, 373

Sujii ER, Togni PHB, Nakasu EYT, Pires CSS, Paula DP, Fontes EMG (2008) Impacto do algodoeiro Bt na dinâmica populacional do pulgão-do-algodoeiro em casa de vegetação. Pesq Agropec Bras 43:1251-1256

SYSTAT SOFTWARE INC (2004) SigmaStat 3.1. for windows. INSO Corporation, Richmond, $\mathrm{p} 848$

Thu Cuc NT, Sujii ER, WIlson L, Underwood E, Andow DA, Hao MV, Zhai B, Chien HV (2008) Potential effect of transgenic cotton on non-target herbivores in Vietnan. In: Andow DA, Hilbeck A, Tuat NV (eds) Environmental risk assessment of genetically modified organisms volume 4: challenges and opportunities with Bt Cotton in Vietnam. CABI, Wallingford, pp 138-175, 360

USDA-APHIS. (2006) Boll weevil erradication. Available at; http:// www.aphis.usda.gov/publications/plant_health/content/printable_ version/fsbollweevil.pdf. Accessed 11 April 2011

Vaissayre M, Hofs J, Schoeman A, Mellet M (2005) Impact des cotonniers génétiquement modifiés sur la biodiversité de la faune entomologique: le cas du coton Bt en Afrique du Sud. Int J Trop Insect Sci 25:63-72

Whitehouse MEA, Wilson LJ, Fitt GP (2005) A comparison of arthropod communities in transgenic $B t$ and conventional cotton in Australia. Environ Entomol 35:1224-1241

Wolt JD, Keese P, Raybould A, Fitzpatrick JW, Burachik M, Gray A, Olin SS, Schiemann J, Sears M, Wu F (2010) Problem formulation in the environmental risk assessment for genetically modified plants. Transgenic Res 19:425-436

Wu KM (2004) IPM in cotton. In: Jia S (ed) Transgenic cotton. Science Press, Beijing, pp 218-224, 312

Wu KM, Guo YY (2003) Infuences of Bacillus thuringiensis Berliner cotton planting on population dynamics of the cotton aphid, Aphis gossypii Glover, in Northern China. Pop Ecol 32:312-318

Wu KM, Guo YY (2005) The evolution of cotton pest management practices in China. Ann Rev Entomol 50:31-52 